\title{
Crossword Puzzle Game in Economic Learning
}

\author{
Have Zulkarnaen* \\ Magister Akuntansi, Fakultas Ekonomi dan Bisnis, Jl. Airlangga No. 4 - 6, Airlangga, Gubeng, Kota SBY, \\ JawaTimur 60115, Airlangga University, Campus B \\ *Corresponding Author: Have Zulkarnaen, Magister Akuntansi, Fakultas Ekonomi dan Bisnis, Jl. \\ Airlangga No. 4 - 6, Airlangga, Gubeng, Kota SBY, JawaTimur 60115, Airlangga University, Campus B
}

\begin{abstract}
Economic learning process in senior high school using lecture method and module method without any innovation is lack interesting, so students are difficult to understand the taught economic material. This study aims is to produce an interesting learning media and easy to understand by using crossword puzzle game on economic learning in senior high school. This research is development of the 4-D model by Thiagarajan (Trianto, 2009: 189) consisting of 4 defining (define), design, development, and dissemination. The research's phase of the model consists of six steps: Potentials and problems, information gathering, product design, validation design, improvements design, and limited product trials. The place of research is in SMA Al-Islam Krian with trials conducted on 20 students of class XI IPS SMA. The result of media development with crossword puzzle game on economic learning in SMA Al-Islam Krian with an average score of $95 \%$, after testing by material experts and media experts and based on observations on students with an average score of 95\%, students' responses of the material get an average score of $88 \%$. The result of the research of crossword puzzle game media test stated that the material expert test obtained very good category, the observation result obtained very good category, and the result of the students response is very good category, so the learning media with crossword puzzle game become feasible to be used for economic learning activity. Learning media crossword puzzle game is easy to use and can increase activity, motivation, and understanding of students which can be made as innovation in economic learning.
\end{abstract}

Keywords: crossword puzzle; inovation; learning economic.

\section{INTRODUCTION}

Education is part of the living process of the state, because the key to success of a nation is measured by the quality of human resources. One effort to improve the quality of human resources is by improving the quality of education. Improving the quality of education can be done through the development of innovative and efficient learning media. In a preliminary study before the research that took place in SMA Al - Islam Krian, found some problems in the process of learning activities. The wastes include not achieving the learning objectives because the learning process of economic subjects in the class less interesting. The learning process uses a lecture method that helps print modules that display the picture is less clear and less interesting, so the delivery of teaching materials becomes less clear accepted by students. Teachers are more active than students because teachers speak a lot and students just listen.

Departing from the background then it is necessary to research to develop interactive learning media on economic subjects in the Basic Competition 3.8. Analyzing the role of economic actors in the Indonesian economic system formulated in the form of development research entitled "Development of Learning Media Crossword Puzzle Game on Economic Subjects ". Selection of basic competencies in the development of this media because of the material is an application in real life. So it takes a strong knowledge of the concept of the material.

According to Samuelson (2014) Economics is the way that people and groups do it to utilize limited resources to acquire various commodities and distribute them for consumption. Means economic lesson is a science that studies the activity. Economic empowerment in particular has existed since junior high school, but more emphasis on high school level that is for IPS majors. Along with the development of education system, especially in Indonesia, economic learning is now a subject that can be studied despite being from other majors in high school. 
Media comes from the word medium which literally means an intermediary or messenger of the message sender to the recipient of the message. In Arabic the media according to Arsyad (2009) is an intermediary message from the sender of the message to the recipient of the message While the learning media according to Munadi (2008), learning media are sources of learning that originated from the teacher referred to as a channel or linker teaching messages held, Created in a planned manner by teachers and educators.

Media Crossword Puzzle Game is a game which in Indonesian terms is better known as Crossword Puzzle (TTS). Crosswords are puzzles that correspond to some hints or definitions that correspond to horizontal and vertical patterns. According to Serna (2011) states that the media crossword puzzle game at the time of applied students feel happy and useful for learning activities. This is also in line with research conducted by Orawiwatnakul (2013).

According to Muchson (2014) the procedure of using Crossword Puzzle in learning is: (1) Describes some important terms or names related to the subjects taught. (2) Prepare a simple puzzle related to the material being taught. (3) Prepare the words of the Crossword Puzzle filling guide. Use the following types: short definition, a category that matches its element, an example, synonym or antonym. (4) Sharing Crossword Puzzles to students. (5) Establish deadlines and reward individuals or groups with the most correct answers.

The purpose of research and development is to design a decent learning media, can be used as a solution in learning problems and add variety in learning activities. Learning media using crossword puzzle games can help students to be more active in learning activities and can help students to understand the material taught and can also help teachers in choosing a good media for the process of learning activities.

Another goal is to design a decent learning media with crossword puzzle game on the material of the Indonesian economic system for high school students, based on the results of the review item by the next material expert is to design a decent learning media with crossword puzzle game on the subject of economic system players Indonesia in high school, based on the observation of student activity and the last is to design a decent learning media with crossword puzzle game on the material of Indonesian economic system at SMA, based on student response result.

Through this research can be produced an interesting learning media in learning activities tailored to the economic material in high school as well as providing input on alternative choices of learning media that are more desirable students and worth to use. The media produced in this study is expected to be applied in economic learning activities, especially on the subject matter of economic system in Indonesia and can be a solution of the lack of variation of learning media contained in SMA.

\section{Materials AND Methods}

The development model used in this study is the 4-D development model adapted from the development of the 4-D model by Thiagarajan (Trianto, 2009: 189) consisting of 4 defining (define), design , development, and dissemination.

The material developed in this product is adjusted to the syllabus used in the school that is in KD analyze. the subject of this study are 20 students . Trial of limited product is done in SMA Al - Islam Krian with the number of respondents as many as 20 students in class XI IPS.

The types of data obtained in this development study are quantitative data and. Quantitative data were obtained from questionnaires, media expert validation papers and limited trials.

Data analysis used in this study are as follows:

- Feasibility analysis of student activity sheets based on crossword puzzles game based on media experts.

- Analysis of student response questionnaire.

$$
\frac{\text { Score }}{\text { Score Maximum }} \times 100 \%
$$

Sumber: Riduwan, 2012 
Based on the objectives and types of research formulated, the data collection techniques used in this study are methods of study, observation, questionnaires, and interviews.

At the stage define is to know of potentials and problems seen are the potentials and problems of Krian Al-Islam students who are less active and lack of material understanding of economic system actors taught in teaching and learning activities. Media innovation that is used also need to be done by teacher as human being educator in learning process. Therefore the authors will develop learning media crossword Puzzle game on the material. Collecting data, the collection of various information and good literature study is in the form of quantitative as well as qualitative by using data collection methods that include: obsevation, interview and questionnaire used as material to develop crossword puzzle game media. This study aims to collect concepts or theoretical foundations to perfect the media to be developed. This preliminary study phase will serve as a basis in the product development stage.

At the product design stage, based on literature study the authors do the initial design of developed media. At this stage, the product design includes the purpose of using the product, who is the user of the product, the description of the components of the product and its use. The purpose of using this product as an interesting learning media, facilitate students in learning to understand the material presented. Learning media with crossword puzzle this game is designed to resemble a crossword puzzle game that contains the answers box questions with the appropriate image design material. Questions are made in the form of an interesting card and given one by one to each student in the group.

In the design validation phase, the researcher validates the design of his product to one media expert and one economics teacher, used in assessing the designed product. In the design improvement phase, this design improvement is done after the instructional media design is validated by the validators. On the validation assessment will beContinuous revisions are then re-validated so on to obtain values that meet the media eligibility criteria of $\geq 61 \%$ based on Likert scale (Riduwan, 2012).

At the development stage is In the trial stage of limited product, the authors compare the effectiveness and efficiency of the situation before and after using the new system, this activity aims to measure the feasibility of learning media to the developed product that is crossword puzzle game in economic learning on the subject matter perpetrator of economic system in Indonesia.

The instruments used in this study are as follows.

\subsection{Media Feasibility Assessment Sheet}

The media feasibility assessment sheet aims to obtain judgments, opinions and suggestions from experts on media quality. This assessment sheet is a questionnaire that contains an assessment of the quality of the media in terms of several components, namely the feasibility aspects of the media content, media aspect format components, visual media aspects, media aspects, and media functional aspects.

\subsection{Sheets Study in the Media Item}

Media crossword puzzle game there are questions about the perpetrators of the Indonesian economic system. Each item on the question card is assessed by the experts using the item analysis sheet to measure the quality of the item item with the media based on the component that is the material content component, the problem construction component, and the language component.

\subsection{Observation Sheet of Student Activity}

This student activity observation sheet was used to observe student activities during the stabilization activity using educational game crossword puzzle game games. This student activity observation sheet contains several indicators of assessment of student activities filled by observers Limited trial activity requires 20 Students formed 5 groups. Each observer observed two groups, and each group consisted of four students.

\subsection{Student Response Questionnaire}

This questionnaire is addressed to students to know students' opinions on motivational game media through crossword puzzle games 
Measurements of this study using a questionnaire questionnaireLikert scale and guttman scale questionnaire. The data obtained were analyzed using feasibility analysis by media expert, analysis of student observation result and student response analysis by using appropriate media crossword puzzle game if result of questionnaire of student response get percentage> 61\% (Riduwan, 2012).

\section{RESULTS AND DISCUSSION}

\subsection{Define}

First, perform a curcum analysis that is the analysis of the front end. The front end analysis is done by defining the curriculum used in the development of a student activity sheet based on crossword puzzles. The curriculum used is the 2013 curriculum that adapts to the curriculum used in SMA AL ISLAM

Second, doing student analysis, The problem is about understanding the concept of the students who are less and not directional. The problem is found from direct observation and interviews both to teachers and with students.

Third, the researcher performs a task analysis that is a set of procedures to determine the task that will be given to the students. The task here is determined to use a crossword game this is adjusted from the existing problems and compatibility with the use of the game.

Fourth, concept analysis is done by identifying the concepts and materials developed. Concept analysis is also done by looking at the detailed syllabus based on core competencies and basic competencies that can later be applied in the game.

Media Crossword Puzzle Game is a game which in Indonesian terms is better known as Crossword Puzzle (TTS).

\subsection{Development}

This stage is the preparation of a crossword puzzle preparation framework covering the following. This stage includes the preparation of contents, the preparation of tests, the selection of media and the selection of formats.

First, the content stage is prepared on the basis of the subject matter contained in the syllabus derived from basic competence. The way in making the contents in this student activities is appropriate based on the literature of competent literature book and through the guidance of both economic lecturer and economics teacher. From these discussions, the essence of the material contained in the material so that the material contained in the lks terebut contains basic concepts and concept maps are short, clear and easy to understand.

Second, the preparation of the test is the design stage which will adjust the test that will be present in the game. The test chosen is to use a crossword puzzle game. Crossword puzzles are chosen because crossword puzzles can improve students' understanding better and make learning more fun and motivate students. The experimental fact of the crossword puzzle game by Kurniawan (2014) also explains when the game is done by the students feel enthusiastic in completing the game.

Third, the selection of incorporating crossword puzzles into economic learning is expected to make learning more interesting and different. media of this game at the time of trial. students think this game is very interesting.

Fourth, the selection of language formats and rules in this game has been adapted to the rules of the Indonesian language is good and correct that is EYD. In addition to this in order to perfect the game format is well structured and the correct language then has been through the stages of guidance to the experts who include material experts and media experts who are competent.

\subsection{Design}

Based on the results obtained from the potentials and problems and data collection in the preparation of media products, design validation by experts, design revisions, then obtained the results made into the design of media products developed and tested products in SMA Al-Islam, Krian. Here is the product board design shown in Figure 1. 


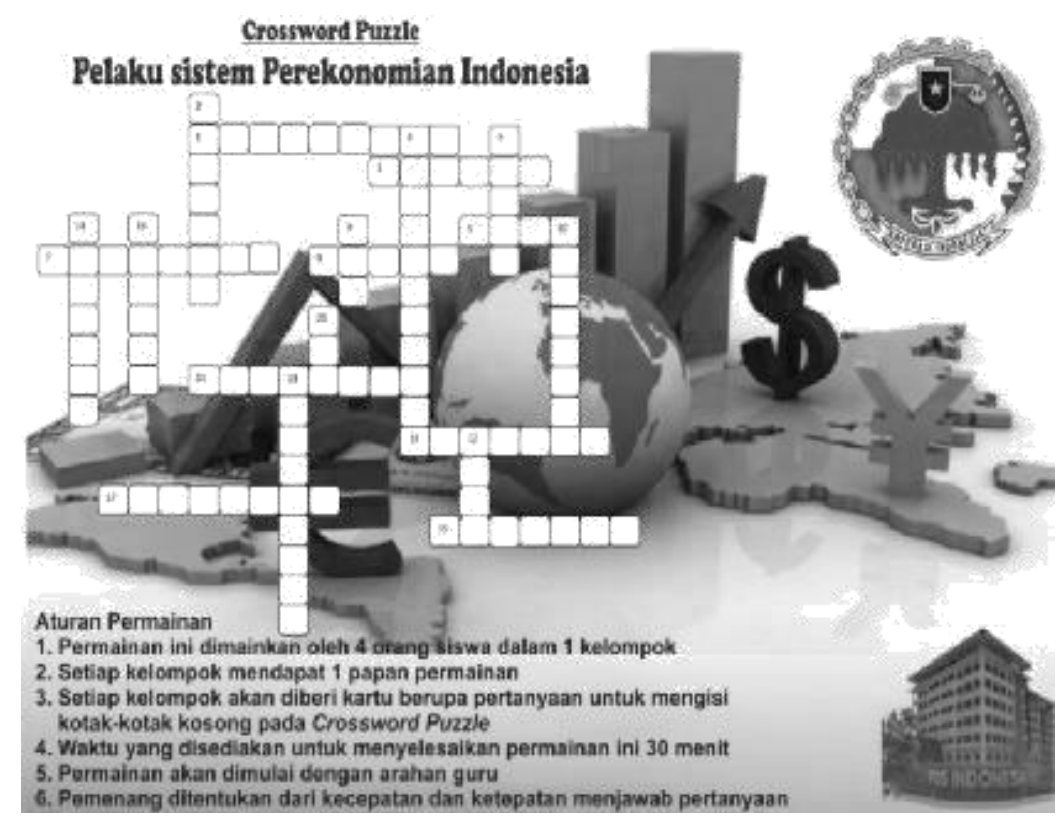

Figure1: Media Board Design Crossword Puzzle Game For Product Trial

The design of crossword media board game puzzle resulted from this research using building images and picture of cooperative logo with the aim of reinforcing who are the perpetrators of economic system in Indonesia. The design was created after passing through several studies of both the media experts, materials, observers and student responses at the time of the study. After the design of the media board, next is the question card design shown in Figure 2.

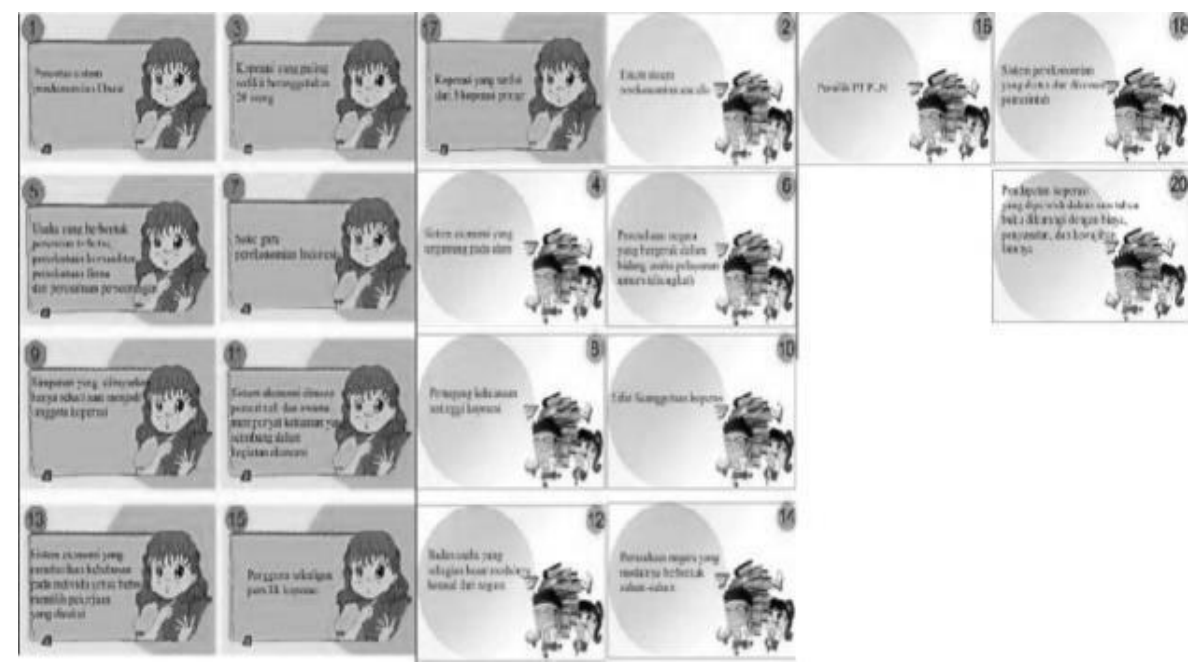

Figure2: Question Card Design Media Crossword Puzzle Game.

The result of this design card is made into two colors to distinguish the questions that the answer is horizontal and vertical. Preparation of this design is done with attention from the study of media experts and material experts to the design feasibility aspects and study to get a good response from students at the time of research. Below is the table of validation data made by the material experts presented in table 1.

Table1: Media Validation Results Crossword Puzzle Game By Media Experts.

\begin{tabular}{|l|l|l|l|}
\hline No & Pernyataan & Hasil Validasi & Keterangan \\
\hline 1 & $\begin{array}{l}\text { to know the technical requirements of the media } \\
\text { crossword puzzle game }\end{array}$ & $92 \%$ & Very good \\
\hline 2 & $\begin{array}{l}\text { to know the aesthetic requirements of the media } \\
\text { crossword puzzle game }\end{array}$ & $\begin{array}{l}\text { to know the educational requirements of the } \\
\text { mediacrossword puzzle game }\end{array}$ & $100 \%$ \\
\hline 3 &
\end{tabular}




\subsubsection{Technical Aspects}

Technical aspect is one of the assessed aspects of this development research by using indicators in its assessment. In this development study there are 5 indicators used in measuring the development of media crossword puzzle game so that the media becomes feasible to do a limited trial, in the development of media products crossword puzzle game is done 2 media experts. The media expert assessed how the media crossword puzzle game and the results obtained from the validation by the media experts obtained technical aspects with average percentage of $92 \%$, the percentage indicates that the development media developed to get very good (Riduwan, 2012).

\subsubsection{Aesthetic Aspect}

The aesthetic aspect is one that is used also in the assessment of media crossword puzzle games in addition to technical aspects and aesthetic aspects. Same with the aspect before the aesthetic aspect also has an assessment indiator of the developed medium, there are 6 indicators of assessment here. Media experts validate the assessment with an indicator on the aesthetic aspect and the result is a 90 percent average percentage earned thus the percentage of crossword puzzle game products developed get very well (Riduwan, 2012).

\subsubsection{Educative Aspects}

Educative aspect is the last aspect in the assessment of crossword puzzle game product developed. The educational aspect is the same as the technical and aesthetic aspects that use the indicator in its assessment. In the assessment conducted by two media experts obtained the results of validation assessment with a percentage average of $100 \%$ obtained from 4 indicators. The results show that the media crossword puzzle game is very good and ready for a limited trial.Media crossword puzzle game on the material of economic system actors in Indonesia declared eligible to be used as a medium of learning. Media feasibility is obtained from media experts based on the results with the percentage of technical aspect $92 \%$, aesthetic aspect $90 \%$ and educational aspect $100 \%$ with average percentage of value obtained is $95 \%$, so meet the criteria very good / very feasible.

After obtaining the media validation results from the experts, the media can be tested limited. A limited trial was conducted in SMA Al - Islam Krian with 20 students as research objects. In this study there are stages of observation, the stages are compiled by using indicators of student activity in learning. Here are the results of observations to students on the media crossword puzzle game on a limited trial presented in table 2.

Table2: Observation Results Observer Students Perform In Learning Media Use Crossword Puzzle Game

\begin{tabular}{|l|l|l|l|l|l|l|l|l|}
\hline \multirow{2}{*}{ Indicator } & \multicolumn{5}{c|}{ Group } & \multirow{2}{*}{ Sum } & \multirow{2}{*}{ Persentase } & \multirow{2}{*}{ Kriteria } \\
\cline { 2 - 10 } & 1Skor & 2 Skor & 3Skor & 4 Skor & 5 Skor & & & \\
\hline Focus and Earning & 4 & 4 & 4 & 4 & 4 & 20 & $100 \%$ & Very good \\
\hline Cooperation & 4 & 3 & 4 & 4 & 4 & 19 & $95 \%$ & Very good \\
\hline Aktive & 3 & 3 & 4 & 4 & 3 & 17 & $85 \%$ & Very good \\
\hline Able To Finish Media & 4 & 4 & 4 & 4 & 4 & 20 & $100 \%$ & Very good \\
\hline $\begin{array}{l}\text { Can be control In } \\
\text { learning }\end{array}$ & 4 & 3 & 4 & 4 & 4 & 19 & $95 \%$ & Very good \\
\hline Average & & & & & & $95 \%$ & Very good \\
\hline
\end{tabular}

(Source: Data processed)

Table 2 shows an overview of student activities in the implementation of product trials. From the results of observations made in table 2 can be obtained data as follows:

The first, shown in the observation of the student activity shows $100 \%$ percentage included in the criterion very good / very decent (Riduwan, 2012), which means 20 students attentively and listening with good learning through the learning media crossword puzzle game on the subject of the economic system perpetrator Indonesia.

Secondly, the observation of the student activity shows the percentage of $95 \%$ which is included in the criterion is very good / very feasible (Riduwan, 2012), which means 19 students do the division of tasks and cooperation at the time of discussion to solve learning media crossword puzzle game on material perpetrator of economic system Indonesia. 
Third, the observation of the student activity shows the percentage of $85 \%$ which is included in the criterion very good / very feasible (Riduwan, 2012), which means 17 Students play an active role in learning by way of opinion and inquire on learning media crossword puzzle game on material perpetrator of Indonesian economic system .

Fourth, the observation of the student activity shows $100 \%$ percentage which is included in the criterion very good / very decent (Riduwan, 2012), which means 20 students able to complete the learning media crossword puzzle game on Indonesian Economic System Performer Matter. Fifth, the observation of student activity shows the percentage of $95 \%$ which is included in criteria very good / very decent (Riduwan, 2012), which means 19 students conducive in learning activities with media crossword puzzle game on Indonesian Economic System Performer Matter. The following table shows the results of student responses to media crossword puzzle game presented in table 3.

Table3: Results of Student's Response to Use of Learning Media Crossword Puzzle Game.

\begin{tabular}{|l|l|l|l|}
\hline Indikator & Jumlahskor & Presentase & Kriteria \\
\hline & yang diperoleh & & \\
\hline Media giving easy to understanding & 90 & $90 \%$ & Very good \\
\hline Media is easy to use & 87 & $87 \%$ & Very good \\
\hline Media more educative and interesting & 93 & $93 \%$ & Very good \\
\hline Increase activity & 91 & $91 \%$ & Very good \\
\hline learning is not boring & 79 & $79 \%$ & Good \\
\hline To increase motivation & 90 & $90 \%$ & Very good \\
\hline cultivate cooperation & 89 & $89 \%$ & Very good \\
\hline Student curiosity increases & 91 & $91 \%$ & Very good \\
\hline Media is easy to remember & 81 & $81 \%$ & Very good \\
\hline Average & & $88 \%$ & Very good \\
\hline
\end{tabular}

(Source: Data processed)

Student responses can be seen using questionnaires penilaiaan student response, This questionnaire is addressed to students to know the opinions of students to the media game motivative through media crossword puzzle game. The questionnaire indicators used as the questionnaire of the respondent response were as follows:

1. Learning Media Crossword Puzzle Game Provides Convenience in Teaching and Learning Activities

According to the results of experiments on learning media developed known the percentage of learning media can help students in teaching and learning activities is $90 \%$ with very good / very decent criteria (Riduwan, 2012). So according to the learning media students who tested try to give ease in teaching and learning activities.

\section{Learning Media Crossword Puzzle Games are Easy to Use in the Learning Process}

According to the results of trials on the media based on students' responses to learning media indicators easy to use in the learning process is known the percentage of $87 \%$ with very good / very decent criteria (Riduwan, 2012). So according to students learning media with crossword puzzle game easy to use in their learning process.

3. The Material Presented with the Learning Media Crossword Puzzle Game is More Educational and Interesting

According to the results of trials on the media based on student responses to learning media indicators developed more educative and interesting is known the percentage of $93 \%$ with very good / very decent criteria (Riduwan, 2012). So according to the students the material presented with the media crossword puzzle game is more educative and interesting than the previous learning activities.

4. Activity Increases with the Medium of Crossword Puzzle Game

According to the results of trials on the media based on students 'responses to learning media indicators developed it can be seen that the students' activity becomes more this is known by a percentage of $91 \%$ with very decent and very good criteria (Riduwan, 2012). So according to students with the learning media crossword puzzle this game can make them more active, active in learning activities at that time. 


\section{The Learning Process is not Monotonous}

According to the results of trials on the media based on students' responses to non-monotonous learning indicators is known with the percentage of $79 \%$ with decent and good criteria (Riduwan, 2012). So with this learning media according to students is not monotonous because not only the material that is delivered but there are games included in it this makes students more enjoy this learning activity.

\section{Generating Student Motivation}

According to the results of trials on the media based on students' responses to student motivation indicator shows the percentage of $90 \%$ with very decent / very good criteria (Riduwan, 2012). So according to students learning media with crossword puzzle this game can provide motivation in the form of learning material with the existing game.

\section{Growing a Sense of Good Cooperation}

According to the results of trials on the media based on student responses to indicators of cooperation sense shows the percentage of $89 \%$ with very decent / very good criteria (Riduwan, 2012). Learning media crossword puzzle game played by the group therefore this media can foster a sense of cooperation when learning activities take place.

\section{Curiosity of Students to the Material Presented}

According to the results of trials on the media based on students' responses to the curiosity indicators of students on the material is very large known percentage results of $91 \%$ with criteria very decent / or very good. Kegiatn learning by using learning media using media crossword puzzle game according to students able to bring a great curiosity to the material, so students listening well.

\section{The Material Being Taught is Easy to Remember}

According to the results of experiments on the media based on students' responses to student indicators, the material taught becomes easy to remember, the result of the percentage is $81 \%$ with very good / very good criteria. Learning by learning media crossword puzzle game according to students makes it easier to remember.

Media crossword puzzle game is said to be feasible if the result of questionnaire of student response get percentage $>61 \%$ (Riduwan, 2012). The table above shows there are nine items that are used to determine the response of students to the media developed the learning media crossword puzzle game provides convenience in teaching and learning activities. Learning media crossword puzzle games are easy to use in the learning process, the material delivered by instructional media crossword puzzle game is more educational and interesting. Activity increases with the medium of crossword puzzle game, the learning process is not monotonous, generate student motivation, cultivate a sense of good cooperation, the curiosity of the students to the material presented, the material taught is easy to remember. The result of questionnaire of student response is get percentage average $88 \%$. It means that developed media get very good criteria / very suitable to be used in learning (Riduwan, 2012).

From the results of this study stated a positive relationship to learning by using media crossword puzzle game on the subject matter of the perpetrators of the economic system in Indonesia on the economic learning of $\mathrm{Al}$ - Islam High School

Krian. This is in line with previous research studies stating that students' cognitive learning achievement on the use of TTS is higher than using LKS media (Sugiharto, 2013). According to wasgito (2014) the benefits of using educational games in the form of crossword puzzles in learning, which can improve student learning activeness. So based on the above discussion, the media crossword puzzle game has been feasible to be used as one of the media used in the learning activities on the subject matter of the perpetrators of the economic system in Indonesia.

\section{CONCLUSiON}

Based on the results of media research crossword puzzle game developed otherwise very feasible as a medium of learning on economic subjects. This media feasibility is generated through the results provided by media experts, material experts, observers and student responses.

Media crossword puzzle game on economic learning that has been done this research has several advantages that is: first, this media can increase student activity in learning activity. Second, can be 
used to overcome the problem of lack of student activity. Third, it can be used at any time with no need of much cost. Fourth, can make learning fun and at the same time easy to understand students. Fifth, making the learning process is not monotonous so it can generate student motivation and curiosity of students to the material presented.

The theoretical implications of research and development of crossword puzzle media of this game, should test the effectiveness of media to determine the achievement of student learning outcomes by using this media. While practical implications suggest to use the media crossword puzzle game on economic lessons in high school, because this media is very well used as one choice of variation of learning to make learning fun and at the same time easy to understand students.

\section{REFERENCES}

[1] Arsyad, Azhar. 2009. Media Pembelajaran. Jakarta: Raja Grafindo Persada. Orawiwatnakul, Wiwat. 2013. Crossword Puzzles as a Learning Tool For Vocalbulary Development. Electronic Journal of Research in Educational Psychology, 11(3), 413-428.

[2] Lutfiyah, Mega Susanti. 2014. Pengembangan media permainan puzzle gambar pada materi system ekonomi di kelas viii smp muhammadiyah 8 tanggulangin. Skripsi tidak diterbitkan. Surabaya: PPs Universitas Negeri Surabaya.

[3] Muchson A.2011.Strategi menjadikan pembelajaran Bahasa Indonesia Tidak Terlupakan Sebagai Upaya Menggalakkan belajar aktif. On line at http://muchsonali.blogspot.com [ diakses tanggal 27 Februari 2015]

[4] Munadi, Yudhi. 2008. Media Pembelajaran (sebuah pendektan baru). Ciputat: Gaung Persada (GP) Press.

[5] Riduwan. 2011. Skala pengukuran Variabel - Variabel Penelitian. Bandung: Alfabeta.

[6] Samuelson. 2014. Pengertian Ilmu Ekonomi Menurut Para Ahli. At online https://www.bersosial.com/ threads/pengertian-ilmu-ekonomi-menurut-para-ahli.12150/ [ diakses tanggal 27 Februari 2015]

[7] Serna, M., \& Azor, J. 2011. Active Learning: Creating Interactive Crossword Puzzle. Congreso internacional de innovacion doconte Universidad politecnica de Cartagena, CMN37/38 cartagena 6,7y 8 de Julio de 2011

[8] Sugiharto dkk. 2013. Studi komparasi penggunaan media tts dan lks pada pembelajaran kooperatif STAD pada materi pokok sistem periodik unsur kelas x semester gasal SMA Negeri 1 Karanganyar tahun pelajaran 2012/2013. Jurnal Pendidikan Kimia, Vol 2 No 1

[9] Sugiyono. 2010. Metode Penelitian (Pendekatan Kuantitatif, Kualitatif, dan R\&D). Bandung: Alfabeta.

[10] Trianto. 2007. Model pembelajaran terpadu dalam teori dan praktek. Jakarta: Prestasi pustaka publisher.

[11] Wasgito, Mohammad Andi.2014. Pengembangan Media Permainan Edukatif Teka-Teki Silang (TTS) Dalam Proses Pembelajaran Siswa Kelas Vii Smp Negeri 2 Kalianget. Jurnal Pendidikan Seni Rupa, Volume 2 Nomor 3 Tahun 2014, 36-43.

Citation: Have Zulkarnaen. "Crossword Puzzle Game in Economic Learning" International Journal of Managerial Studies and Research (IJMSR), vol 7, no. 12, 2019, pp. 54-62. doi: http://dx.doi.org/10.20431/23490349.0712008.

Copyright: (0) 2019 Authors. This is an open-access article distributed under the terms of the Creative Commons Attribution License, which permits unrestricted use, distribution, and reproduction in any medium, provided the original author and source are credited. 